

\title{
New Experimental Method for Consolidation some Refractory and Nonmetallic Powders
}

\author{
A. Peikrishvili, L. Japaridze, N. Chikhradze, Z. Chikviladze
}

\section{To cite this version:}

A. Peikrishvili, L. Japaridze, N. Chikhradze, Z. Chikviladze. New Experimental Method for Consolidation some Refractory and Nonmetallic Powders. Journal de Physique IV Proceedings, 1997, 07 (C3), pp.C3-67-C3-72. 10.1051/jp4:1997314 . jpa-00255427

\section{HAL Id: jpa-00255427 https://hal.science/jpa-00255427}

Submitted on 1 Jan 1997

HAL is a multi-disciplinary open access archive for the deposit and dissemination of scientific research documents, whether they are published or not. The documents may come from teaching and research institutions in France or abroad, or from public or private research centers.
L'archive ouverte pluridisciplinaire HAL, est destinée au dépôt et à la diffusion de documents scientifiques de niveau recherche, publiés ou non, émanant des établissements d'enseignement et de recherche français ou étrangers, des laboratoires publics ou privés. 


\title{
New Experimental Method for Consolidation some Refractory and Nonmetallic Powders
}

\author{
A. Peikrishvili, L. Japaridze, N. Chikhradze and Z. Chikviladze \\ Academy of Science of Georgia, Institute of Mining Mechanics, 7 E. Mindeli St., 380086 Tbilisi, Georgia
}

\begin{abstract}
In order to obtain high-dense cylindrical compacts the coated powders on the base of tungsten, tungsten carbide and graphite were consolidated by hot shock wave compacting technology. As investigation showed utilization of coated powders has some advantages and enables to obtain compacts near theoretical density with high value of hardness. It was established that at high temperatures under shock loading W and WC base coated powders have quite different mechanism of deformation - like deformation under very high pressure and individual grains are characterized by intensive fragmentation.
\end{abstract}

Résumé. Pour obtenir les modèles cylindriques d'haute densité, les poudres plaquantes baseés sur wolfram, carbure de wolfram et grapfite ont été consolidées á l'aide de technologie de choc-onde.

Les investigations font preuve des avantages d'utilization des poudres plaquantes et de possibilité d'obtanir les modèles pressées d'haute dureté et avec la densité pareille á la valeur theoretique.

On avait établi, que sous les températures hautes et choc-onde chargement les poudres de wolfram ont le mécanisme de deformation different, pareil à la deformation sous la pression très haute et les grains isolés sont caractérisés par la fragmentation intensive.

\section{INTRODUCTION}

Shortage of data concerning the study of compacting of the refractory and non-metallic alloy powders is caused by large number of technological difficulties bound with shock-wave processing. Difficulties are related to the impossibility of direct compacting of powders on WC, W and graphite base. The problem is that necessary pressure for plastic flow of consolidated particles for formation of common boundaries exceeds ultimate strength of steel container. In [1-3] is shown the positive role of high temperature in the processes of consolidation of hard alloy powders. Application of high temperatures allows the consolidation mechanism to work on which is characterized by plastic flow and mutual collision on compacting particles resulting in the melting of their surfaces and formation of common boundaries.

Using the coated powders as a starting materials in comparison with mechanical mixtures must have some advantages and enable the consolidation mechanism to work on at essentially low intensity of loading.

In the present paper the results of investigation, dedicated to the compacting of coated W, WC and graphite powders by hot shock wave technology and obtaining of high-dense cylindrical compacts are described. 


\section{EXPERIMENTAL}

In order to compact coated refractory graphite powders in hot conditions there was used axisimmetrical scheme of loading presented in fig.1.



Figure 1: The experimental arrangement of high temperature shock wave compacting.

1. Cylindrical Steel container 2. Consolidating powder 3. Thermo isolation layer. 4. Heating plugs. 5. Cyllindric paste - board. 6. Explosive powders. 7. Detonation cord.

Consolidating powder (2) is placed inside of container (1) with preliminary density of $70-75 \%$ (from Theoretical density). The container is shut from both sides with plugs. Simultaneously, the plugs are used a heating contacts (4).

Around the container is situated cyllindring paste - board (5) filled with explosive powder (6). Using the method of resistance the heating of assembly up to desired temperature is reaching, while initiation of explosive materials-using the detonator and detonating cord (7).

The experiments were carried out in the region of temperature $20-1200^{\circ} \mathrm{C}$. The ammoniate (detonation velocity $3.6 \mathrm{~km} / \mathrm{sec}$ ) was used as an explosive material.

It is worth mentioning that all indicated pressure values corresponds to the pressure value on the steel container's wall.

The fig. 2 illustrate the powders of W and graphite coated with $\mathrm{Ni}$ and WC coated with Co which were used as a starting materials for commixing.

Macrostructures shown in the fig. 4 demonstrate a positive pole of temperature and of hot shock wave compacting technology. Utilization of graphite coated powders and the compacting at $800^{\circ}$ enable obtaining non-porous compacts of $\mathrm{C}$-Ni compositions with graphite content up to $50 \%$ (fig. 4b). Under usual conditions the maximum graphite content does not exceed 30\% [4]. The comparison of W-Ni Compacts macrostructures to each other (fig. 4c,d) shows that while the temperature increases the possibility of cracks formation decreases and under $800^{\circ}$ (fig. $4 \mathrm{~d}$ ) no cracking occurs and high quality compacts are obtained.

The fig. 5 demonstrates the results of the hardness distribution investigation in compacts produced at different compacting conditions.

As is seen from the hardness distribution the loading intensity and compacting temperature have a substantial impact on the hardness value of compacts. 




a)



b)

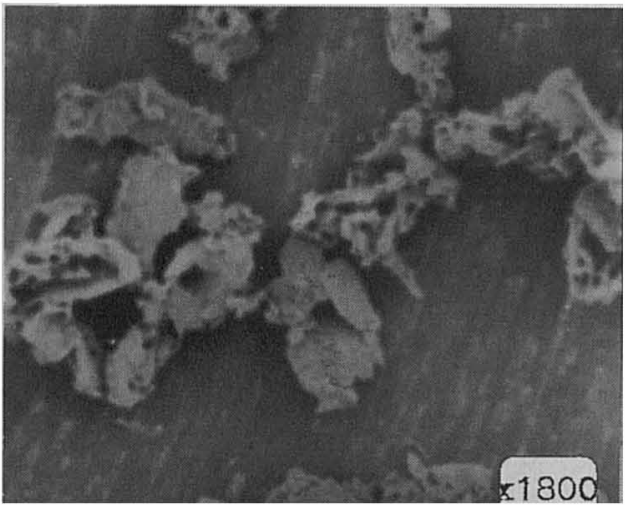

c)

Figure 2: Coated starting powders.

a) W-Ni composition; b) WC-Co composition; c) Ni-C graphite composition

Growth of the loading intensity under compacting equal temperatures (fig.5a) results in producing compacts with higher value of hardness. It is likely to be occurred due to strengthening of the nickel matrix. Compacting process under high temperatures results in producing high dense compacts, however with low value of hardness and this can be explained by disstrengthening of the nickel matrix.

In contrast to above mentioned, during W-Ni compacting process the growth of temperature is accompanied with the increase of the obtained compacts hardness and distribution of hardness along the cross-section becomes stable. At $800^{\circ} \mathrm{C}$ compacted samples are characterized with a very high hardness which is rather unusual for these compositions.

In the fig. 6 are shown microstructures of compacted WC-Co formed from mechanical mixtures as well as from coated powders under equal loading conditions. 




a)



c)



b)



d)

Figure 3: Macrostructure of compacts of $\mathrm{Ni}-50 \% \mathrm{C}$ graphite and $\mathrm{W}-20 \% \mathrm{Ni}$ composition compacted from coated powders with intensity of loading $10 \mathrm{GPa}$.

a) $\mathrm{Ni}-50 \% \mathrm{C}$ compacts. $\mathrm{T}=20^{\circ} \mathrm{C}$. b) $\mathrm{Ni}-50 \% \mathrm{C}$ compacts. $\mathrm{T}=800^{\circ} \mathrm{C}$.

c) $\mathrm{W}-20 \% \mathrm{Ni}$ compacts. $\mathrm{T}=200^{\circ} \mathrm{C}$. d) $\mathrm{W}-50 \% \mathrm{Ni}$ compacts. $\mathrm{T}=800^{\circ} \mathrm{C}$.

As is seen from microstructures the carbide grains differ essentially from each other. If in case of mechanical mixture there are observed in WC grains the traces of plastic deformation as sliding lines and twinnings (fig. 6a), having dealt with coated WC grains we can observe the traces of strong fragmentation (fig.6, b). Such an evident difference between microstructures might be explained by different deformation mechanisms on the shock wave front.

It can be supported that under high temperatures $800-1000^{\circ} \mathrm{C}$ and more, there occur a melting of coated Co layer during the loading on the shock wave front and separate WC particles become subjects of hydrodynamic influence. It is likely that the mechanism of deformation intrinsic for very high pressure takes palace, grains are being strongly compressed and all this results in an intensive fragmentation. The oval shape of WC grains and their symmetric fragmentation contribute to the aforementioned. 




a)



b)

Figure 4: Hardness distribution in compacts obtained from coated powders by shock wave loading. a) C-Ni compostion. b) W-Ni compostion.

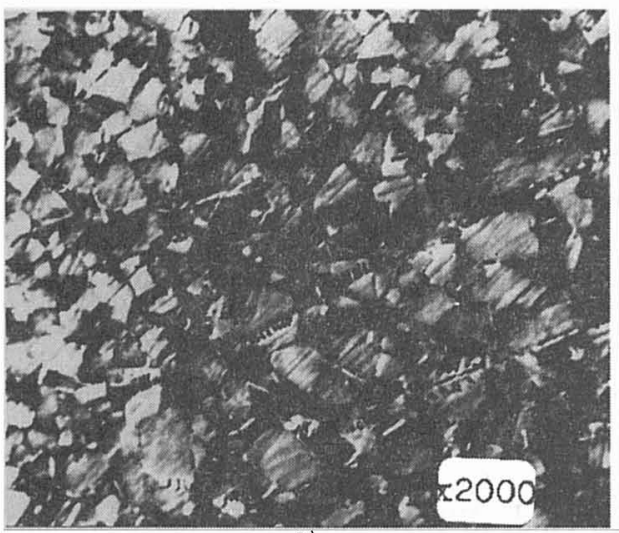

a)



b)

Figure 5: Microstructures of WC-Co powders hot compacted at $\mathrm{T}=1000^{\circ} \mathrm{C}$ and $\mathrm{P}=10 \mathrm{GPa}$.

a) Mechanical mixtures of WC-Co. b) WC coated by Co.

In the fig. 7 there are shown curves of hardness distribution for heavy alloys compacted from mechanical mixtures as well as from coated powders.

As it is seen from the hardness distribution, alloys obtained from coated powders with the by far highest content of "soft" phase (W-20\%Ni) are characterized with substantially higher values of hardness than mechanical mixtures. The above mentioned once again confirms above stated suggestions regarding the deformation hydrodynamic mechanism and outlines its practical advantages.

As it is seen from the hardness distribution, alloys obtained from coated powders with the by far highest content of "soft" phase (W-20\%Ni) are characterized with substantially higher values of hardness than mechanical mixtures. The above mentioned once again confirms above stated 
suggestions regarding the deformation hydrodynamic mechanism and outlines its practical advantages.

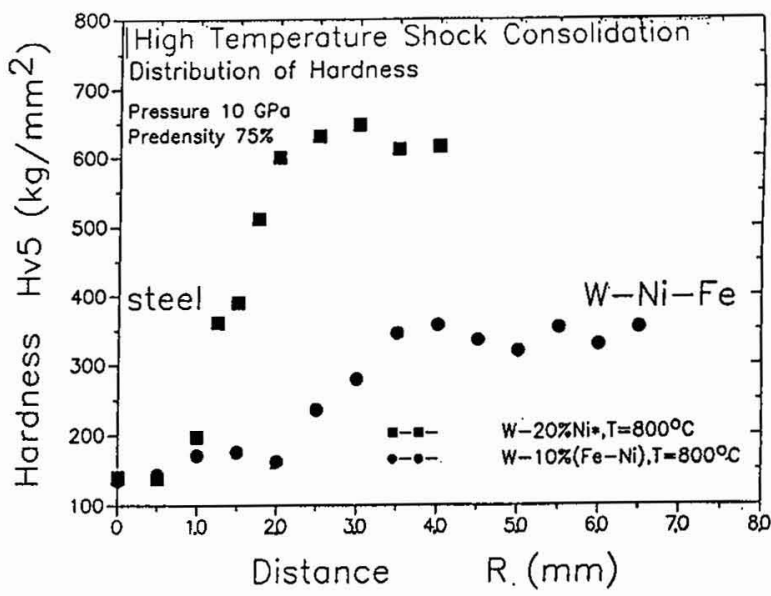

Figure 6: Distribution of hardness in compacted heavy alloys at $\mathrm{T}=800^{\circ} \mathrm{C}$ and $\mathrm{P}=10 \mathrm{GPa}$.

In conclusion it can be stated that the simultaneous utilization of coated powders as initial materials and of shock wave compacting technology permits to obtain compacts from refractory and graphite based powders with a density near theoretical values and with high physicalmechanical properties.

All this favours to contemplate the proposed experimental method as attractive and prospective one for producing materials with new properties.

\section{FINAL REMARKS}

Utilization of coated powders as initial materials and of hot shock wave compacting technology allows under relatively low pressures (up to $10 \mathrm{GPa}$ ) to snap into action the mechanism of deformation characteristic for very high pressure and to obtain compacts of refractory and graphite based powders near theoretical density with improved physical-mechanical properties.

\section{REFERENCES}

1. Jim D. Mote and Joan J. Fitzpatric. Proceedings of the conference on Emergent Process Method for High - Technology Ceramics, 1982, p. 695-710.

2. L. Japaridze, A. Peikrishvili et al., Importance of preheating at dynamic consolidation of some hard materials, Shock wave and High - Strein - Rate phenomena in materials, completed by M. A. Meyers, L. E. Murr and K. P. Staudhammer. Marcel Dekker, INC. N.Y. 1992.

3. Prümmer Explosivverdichtung pulvriger Substanzen, Springer - Verlag Berlin heidelberg New York, London, Paris, Tokyo, 1987.

4. A. A. Kiiski, P. R. Ruuskanen et al., Explosive compaction of copper and graphite powder mixtures, shock wave and High - Strain - Rate Phenomena. Edited by L. E. Murr, K. P. Staudhammer and M. A. Meyers. Elsevier. 1995 pp 109-115. 